\title{
What is worth a qualification? \\ Approaches towards the Recognition of Vocational Qualifications and Competences acquired abroad
}

\author{
Christiane Eberhardt, Silvia Annen \\ Federal Institute for Vocational Education and Training, Germany
}

\begin{abstract}
In Germany the recognition of foreign qualifications and competences is of high political relevance due to the severe problem of a skills shortage. Thus, in April 2012 the "Federal Recognition Act" entered into force in order to improve the assessment and recognition of vocational qualifications achieved abroad. The presented research project MoVA reflects the implementation of this act by analyzing the strategies, concepts and practices of other countries regarding recognition of vocational competences and qualifications. In this contribution we focus on the present status in Germany and counter it with the approaches implemented in Denmark, Canada and Australia.
\end{abstract}

\section{Introduction}

The MoVA project is aimed at making available experiences from selected countries which have existing models and statutory regulations for the recognition of foreign vocational qualifications and competences. In this context the term "qualification" is understood to mean a "systematic linkage of acquired competences and occupational tasks" [18:501]. Attention will focus on countries which have explicitly recruited skilled workers from third countries in recent decades (Norway, Canada, Denmark, Australia and Switzerland); the recognition regulations and procedures that exist in those countries will be examined in more depth. To this end, the principles underlying the models in the respective countries, their design and institutional embedding will be presented with reference to country studies and investigated by means of qualitative interviews. Alongside this monitoring approach addressed to the educationsystem level, the procedures in use - and hence consideration of the concrete implementation level constitute a secondary focal point of the project. Aspects to be studied are the criteria for assessment, the extent of use and de facto usage of the procedures, and the potential benefits from the viewpoints of different stakeholders. With this approach the project contributes to the ongoing discussion in Germany about permeability and equivalence of educational pathways.

\section{Methodology}

The MoVA Project will be implemented via several research phases. In the first project phase, existing regulations in at least four European countries and four non-European countries will be monitored and defined in specific terms. This will form the basis for the stipulation of four countries, the models of which will be subjected to a more detailed analysis. "Detailed case studies" will be drawn up for the four selected countries. The case studies will be backed up by interviews with "key persons" from the fields of policymaking, practice and research. The interviews will be coded and evaluated. In methodological terms, our approach will be aligned towards the qualitative content analysis in accordance with Mayring 2002 [15]. A further stage will involve the exchange and synchronisation of the codes with other academic researchers involved with the project. Within the context of the various approaches actor-centred institutionalism and governance forms a theoretical basis for the analysis of the underlying coordination processes as well as for their implementation and institutional integration.

Our research questions are geared towards the following headings:

Principles: What were the guiding principles and driving forces for the recognition regulations?

Design: On which methodological and conceptual foundations is recognition constructed in the different countries? Is there any legally binding basis, and what is its nature? What function is ascribed to recognition? What legal effects are associated with recognition? (Institutional) framework conditions: How were the models/procedures introduced? What preparation 
period was necessary for this? What resistances and problems arose in the process?

Stakeholder constellations: Which stakeholders are involved in implementation? How do the stakeholders work together in the field? Which constellations of stakeholders prove to be favourable, and which do not? Where do tensions occur between them? In which institutional context do which stakeholder constellations develop? Are these comparable across the countries studied?

Procedures/examination criteria: Which procedures are in use? Which measures, if any, are in place before or after the procedures? Which cooperation exists with relevant stakeholders? Which rights/obligations for the applicants are associated with recognition procedures? How (and with whom) were the procedures developed? How is the success of procedures assessed? What do recognition procedures cost and who bears the costs? Are there individual support structures for the applicant?

Implementation: Which factors have proved to be beneficial in the operative implementation? How do the various stakeholders rate the success of the models? What are the motives of those seeking recognition (who seeks recognition and for what reason?)

The collation of the results will lead to the identification, systematisation and classification of the models and procedures deployed for the recognition of professional and vocational qualifications acquired abroad and of their methodological conceptual principles, the prevailing institutional conditions and of their de facto use.

\section{Assessment and recognition of foreign qualifications in selected countries}

The MoVA Project is still in its initial phase. We present our first impressions below.

\subsection{The European perspective - recognition of qualifications acquired abroad on the basis of occupational standards}

The debate surrounding the recognition of qualifications obtained abroad is nothing new across Europe. Approaches towards bilateral, sectoral and/or multilateral regulation of such recognition extend all the way back to the 1950's.

A series of European Directives stretching from the 1960's and culminating in the EU Recognition Directive 2005/36/EC form "milestones" along the way. This Directive applies to regulated occupations only. An occupation is deemed to be "regulated" if the access to and the exercising of such an occupation is linked with the necessity to provide evidence of a certain qualification via the legal and administrative provisions of the member states. Member states decide autonomously on whether an occupation is regulated or not. The necessity for a formal procedure for the recognition and evaluation of professional and vocational qualifications is to this extent dependent on whether the respective professional or vocational qualification is regulated or not in the target countries (i.e. in the countries in which utilisation of the professional or vocational qualification on the labour market is being sought). Around 800 categories of regulated occupations currently exist in the Member States. Access to these occupations is frequently governed by individual state legal provisions in the countries. In 2011, "Directive 2005/36/EG on the recognition of professional qualifications", the provision that had applied thus far, was updated. The aim is for this to be implemented in national law by 2014. The objectives include facilitating mutual recognition of professional and vocational qualifications in Europe via the use of a voluntary electronic European professional card (EPC) associated to a recognition procedure carried out within the Internal Market Information System [13]. Within the scope of the EU Directive, recognition of the vocational qualification is expressed on the basis of duration of training and certificates and diplomas. Such an input-driven procedure, however, leads to "asymmetry" that is described by Beyer Paulsen [2:23]: "Some Member States have a policy of strong State regulation of access to pursuing a profession, while others largely leave this up to the social partners or professional bodies (...) and in yet others there is, by and large, no regulation at all. Certain professions such as education and training opticians require postsecondary education in some Member States, while the same profession requires VET in others. (...) The main difficulties in administering the directive(s) could be said to be the lack of adequate information on qualifications in other languages, "asymmetry" of professions covered, and the static character of the instrument itself (in a world of constant change)." Further asymmetry occurs by dint of the fact that occupations are regulated in some countries but not in others. In some European countries, procedures have been developed to ascertain how qualifications people have acquired within other national contexts relate to the existing (non-regulated) qualifications in the home country. We may assume that associated recognition on the domestic labour markets is the essential reason why people submit relevant applications and undergo assessments.

Below we present two countries from Europe in which assessment and recognition of professional and vocational qualifications acquired abroad is the object of statutory regulation - Germany and Denmark. The 
two countries border each other and are close both geographically and in terms of the structuring of their vocational education and training and labour markets.

\section{Germany}

The "Law to improve the assessment and recognition of professional and vocational education and training qualifications acquired abroad" (referred to in abbreviated form as the "Recognition Act") has been in force in Germany since 2012. It is aimed at German nationals and residents with qualifications acquired abroad and at foreigners intending to migrate to Germany. The law covers only occupations that are governed by Federal law. These encompass 84 regulated occupations (including the craft trades where a licence and possession of a master craftsman qualification is required in order to operate a company) and 519 non-regulated occupations (i.e. the 330 dual training occupations and 180 advanced training occupations that are governed by the Vocational Training Act and the Crafts and Trades Regulation Code). For the first time, the Recognition Act provides skilled workers in non-regulated occupations who do not require formal recognition with an opportunity to have their qualification assessed and thereby improve their chances on the labour market [3: 21]. "Recognition" in terms of the Act is understood as the assessment of the foreign qualification towards the German reference occupation. Thus the Recognition Act does not apply neither to the recognition of studies and examinations completed abroad within the context of admission to higher education nor to the recognition of school leaving certificates or to the recognition of higher education qualifications which do not lead to a regulated occupation (e.g. mathematician, chemist, economist). In 2012 approximately 11.000 people applied for recognition - in 7.458 cases full or partial equivalence with the relevant German reference qualification has been confirmed [3: 44]. The "equivalence check" takes place on the basis of stipulated formal criteria such as content and duration of training. The procedure itself is subject to a charge from $€ 100$ to $€ 600$ depending on the amount of time and expense incurred [5: 15]. If the required evidence cannot be submitted, it is possible for a skills analysis to be carried out for the purpose of ascertaining occupational competences (e.g. via a specialist oral examination or work sample). In such cases, an applicant may incur further costs. In case there are substantial differences between the foreign and the German reference qualification, "partial equivalence" will be confirmed. Such an assessment notice lists existing qualifications and the significant differences between the foreign and German qualifications. This means that applicants may be able to compensate for any deficits by undertaking continuing training and then be in a position to apply for full equivalence. Assessment takes places at competent authorities such as the Foreign Skills Approval Competence Centre of the Chambers of Industry and Commerce (IHK FOSA) and at 53 regional Chambers of Skilled Crafts that are responsible for the recognition especially in the craft trades. The German Confederation of Crafts and Trades assesses the recognition rate as "thus far": in the first six months following the enactment of the Recognition Act 57 per cent of the applications submitted were accorded full equivalence and 33 per cent partial equivalence. Most of the applications asked for recognition in the occupations of electrical technician, hairdresser and motor vehicle technician [7]. Daike Witt, Vocational Education and Training Advisor at the German Confederation of Skilled Crafts puts the challenges of recognising foreign qualifications in a nutshell: "Submissions regarding qualifications from 77 countries of origin have already been received by the Chambers. In order to be able to make a decision on equivalence, the Chambers of Crafts and Trade require information about the various educational systems and about the foreign qualification in particular" [7]. Representatives from the Foreign Skills Approval Competence Centre (IHK FOSA) of the Chambers of Commerce and Industry state that the "Recognition Act" brought applicants benefits regarding the transfer from temporary work to a fulltime permanent contract of employment [10]. Although the implementation of the law is judged to be successful, the Report on the Recognition Act, which supports enforcement and was adopted by the Federal Cabinet on 2 April 2014, describes areas in which further action is required. Aspects referred to include the following.

- The development of uniform standards for equivalence assessment, basic criteria for the exercising of the occupation, uniform regulation of requirements regarding language knowledge and consideration of occupational experience.

- The standardisation of administrative structures at the competent bodies and in the federal states in order to guarantee efficient implementation of the law.

- The expansion of existing information provision.

- The stipulation of a standard scale of fees for the carrying out of the procedures which does not deter those interested in seeking recognition whilst also not jeopardising the "highly demanding and qualityassured recognition procedure" [3: 16].

\section{Denmark}

In addition to compliance with EU regulations, the rationale and justification for preparing and passing the legislation in Danish Parliament originate partly from 
identified labour market prognoses stating that in 2020, Denmark will face a shortage of persons holding certificates from EQF levels 4 to 7 [12: 40]. Moreover the legislation is seen as a means for promoting open and inclusive behavior towards foreigners coming to Denmark. The assessment of foreign qualifications has therefore been on the Danish agenda since 2001. In order to integrate skilled workers at the medium and higher qualifications level into the Danish labour market, procedures that make it possible to evaluate foreign professional and vocational qualifications have been developed. The legal basis is formed by two laws: Since 2010, the recognition of qualifications which fall into the category of regulated occupations in Denmark has been covered by the "Act on the Right to Exercise Certain Professions in Denmark" (Consolidated Act No.189). Procedures for the evaluation of nonregulated occupations have been in existence since 2001 and are governed by the "Assessment of Foreign Qualifications etc. Act" of 2007 and the associated decree from 2003 "Assessment of Foreign Qualifications etc. Order". All persons who have acquired an education or training qualification abroad may claim the right to an assessment. Furthermore, the right to obtain an assessment lies with any employer who requires assessment in order to decide whether or not to hire somebody with foreign qualifications, any authority that requires an assessment for its administrative procedures, any educational institution and unemployment insurance fund considering an application for admission from a holder of a foreign qualification. The assessment is free of charge and normally takes between 1 and 2 months.

The "Danish Agency for Universities and Internationalisation" is the central institution commissioned with the task of conducting recognition procedures. The procedure of assessment/recognition of qualifications takes place the basis of the following documents:

- a letter of application or an application form,

- proof of nationality - e. g. copy of pages in passport,

- evidence of formal qualifications (diploma, certificate, attestation of competence, certificate of apprenticeship or the like).

- a list of subjects regarding the applicant's education,

- documentation of any relevant professional experience,

- an authorisation certificate from the country of the applicant stating that she/he is qualified to perform the profession applied for in Denmark (this specifically relates to the right to perform regulated professions in Denmark),

- contact with authorities in the country of education [12:41].

The assessment issued by the Agency declares whether a qualification acquired abroad corresponds with a
Danish qualification. If this is not the case, supplementary measures necessary for the achievement of full occupational equivalence are stated.

Interestingly, the law for the assessment of foreign qualifications is also targeted at connections and transitions within the Danish educational system rather than merely focusing on improved labour market access. The result of an assessment may be that the qualification completed is categorised with regard to access to further education and training programmes [14]. The Danish Assessment Law thus also focuses on the expansion of the employment and training prospects of applicants. Unlike in Germany, the main emphasis is on the "fundamental comparability" of qualifications rather than on the assessment of equivalence - i.e. assessment is issued on the basis of a comparison of learning outcomes. According to the view of a representative of the Danish Agency for International Education, this focusing on learning outcomes makes it easier to assess qualifications acquired abroad ("even though there may be many differences in content in the education and training courses" [18]) whilst admitting that there are various pathways towards achieving the same learning outcomes. In Denmark, there is robust application of the principle that an education or training qualification that has been assessed results in the same entitlements as a qualification obtained in the country itself. For this reason, assessment leads to both de-facto and de-jure recognition and opens up access to higher education, further training and unemployment insurance [18]. The assessment of foreign professional and vocational qualifications is also used as a means of active recruitment policy for nationals of third states as well as being offered as part of special programmes like the "Green Card Scheme". The "Green Card Scheme" is offered by the Danish Government as a procedure to applicants coming from outside EU/EEA countries as an opportunity for being granted a residence permit for the purpose of seeking work, and subsequently working, in Denmark. A residence and work permit under the Green Card Scheme is issued on the basis of an individual evaluation using a point system designed to assess the likelihood that the applicant will be able to find qualified work in Denmark. If a person is granted a residence permit under the Green Card Scheme, she/he does not need to obtain a work permit. A residence permit under the Green Card Scheme gives the applicant the right to carry out paid or unpaid work [12:42].

Nevertheless, action is also required in Denmark. As in Germany, verification of the authenticity of certificates has proved to be time consuming [12: 43]. With regard to duration of processing, it has been identified that in

\footnotetext{
1 More at https://www.nyidanmark.dk
} 
Denmark, where training-related final qualifications ("learning outcomes") are assessed, an average of two applications can be handled per day. In comparison to this, the German equivalence assessment is much more time consuming. Nevertheless, representatives of the Danish Ministry of Education [5] believe that the country and occupational profiles developed for the recognition process in Germany (see www.bqportal.de) are instruments that will facilitate acceleration of the procedures in the medium term. There is an absence of such internal tools in Denmark. Preliminary experiences with the assessment system show that the purpose of going through an assessment procedure is mostly motivated by getting employment in Denmark (65 per cent in 2011). At the same time applications related to educational matters such as admission to Danish education and training institutions are increasing (from 22 per cent in 2007 to 35 per cent in 2011). In 2011, as in 2009, the 30 per cent of educational pathways to be assessed was composed of social, commercial and business certificates. The group of humanities amounted to 14 per cent. 87 per cent of applications for assessment of foreign qualifications are made by the holders themselves whereas seven per cent of the assessment applications were forwarded by public employers in order to be in a better position to determine salaries for newly employed foreigners. 65 per cent of the applications were aimed at providing the applicant with support when applying for job and 35 per cent were related to entry procedures for further education. 63 per cent of the applications related to women. 38 per cent of the assessments from 2011 were made less than five years after the completion of education. 64 per cent of the assessments were made less than ten years after the completion of education [8:42].

\subsection{The perspective beyond Europe - recognition of foreign qualifications on the basis of existing labour market requirements}

In Australia and Canada, the recognition of occupational competences acquired abroad is aligned towards the needs of the labour market and is the expression of an active migration policy. The examples of both countries show that elements like a pointsbased system, regional migration programmes and a certain adjustment towards the endemic occupational skills shortages especially via shortage occupation lists are quite common elements of the national approaches. Still the institutional structures, the involved stakeholders and their roles as well as the concrete methods used differ. One clear difference at the specific implementation level is the fact that Australia has a National Qualifications framework that is used as a standardised reference value for recognition. No uniform standard of this kind is currently in place in Canada.

\section{Canada}

Migration in Canada has been steered by a pointsbased system since 1967 . On this basis, migrants are chosen depending on their education, work experience and language competences. [16:1]. In 2008, the Government imposed a general restriction on this points model. Since this time, applicants have been required to be a qualified skilled worker in one of the 29 shortage occupations, be in possession of a job offer in Canada or intend to complete a programme of doctoral studies in Canada. The introduction of this restriction to admission shows the importance of labour market requirements for access and the usability of foreign qualifications and competences by the immigrants. Assessment criteria were added to the points system in categories such as age and adaptability $^{2}$ accordingly. Alongside this approach located at a national level, the so-called „Provincial/Territorial Nominee Programs“, which are aligned towards regional labour market requirements [1:18f] are becoming increasingly significant.

The so called Temporary Foreign Worker Program's purpose is filling genuine and acute labour market needs. Furthermore temporary workers and international students with Canadian work experiences can apply for immigration through the Canadian Experience Class. This category was introduced in 2008 due to an assumed positive prediction regarding the integration of these people [8:230].

Within the area of regulated professions, the recognition is mainly carried out provincially postimmigration by the regulatory bodies. Regarding unregulated occupations the employers are mainly responsible for the recognition post-immigration [16: 31]. The vast majority of occupational activities in Canada fall within the area of non-regulated occupations, which are also the focus of the MoVA Project. Non-regulated occupations do not require any licensing from a regulatory authority. Skilled workers, employers and other organisations can seek the assistance of the „Canadian Information Centre for International Credentials" which provides support for the recognition and assessment of certificates and qualifications. Credential assessments proofs whether the foreign credentials are equivalent to the Canadian standards, determine whether the applicant needs more training, education or Canadian work experience, helps him to understand the types of jobs for which he might be qualified and makes the foreign qualifications more understandable for potential employers. The

\footnotetext{
${ }^{2}$ http://www.cic.gc.ca/english/immigrate/skilled/apply-factors.asp
} 
recognition practice of foreign qualifications in Canada is shaped by a number of policy documents on international, national, provincial, and organizational levels. Credential assessment organizations, especially the five provincially mandated assessment organizations, adhere to the so called General Guiding Principles for Good Practices in the Assessment of Foreign Credentials and the Recommendation on Criteria and Procedures for the Assessment of Foreign Qualifications These General Guiding Principles result from the collaboration of the Alliance of Credential Evaluation Services of Canada (ACESC). The purpose of this Alliance was sharing information on assessment methodologies used across Canada, establishing codes of good practice and identifying common assessment principles [8: 241]. There are generally two areas of assessment: credentials (including education, training, and job experience) and competency assessment. In the past credential based assessment has been the standard practice, while competency-based recognition becomes more important in the recent years [8: 239].In Canada, it is noticeable that many levels of government and organisations with various roles and responsibilities are involved in the recognition process - 13 jurisdictions, 55 ministries, more than 50 regulated occupations, more than 400 regulatory bodies, 5 assessment agencies, more than 240 post-secondary institutions, and a large community of immigrant service agencies, as well as numerous employers [TASC, 2010 quoted after 8: 232]. There is, however, clearly a need to standardise the recognition process. This requirement has found its expression in the "Pan-Canadian Framework for the Assessment and Recognition of Foreign Qualifications", which has been agreed between the Federal and Provincial governments and the governments of the territories. Alongside this framework the so-called "commitment to foreign credential recognition" and the "Foreign Credentials Recognition Program" also act as essential elements for the recognition of foreign qualifications and competences.

As the recognition of foreign credentials is a priority of the Canadian governments they have delegated and funded initiatives to better recognize immigrants' qualifications, and to enhance their access to professions. The aim is to increase the procedures of the regulatory bodies regarding timeliness, transparency, consistency, and accountability [8: 230]. The migration process in general is supported by various initiatives, programs and measures like the Canadian Immigrant Integration Program (CIIP), the „Career Bridge“ Program, the Enhanced Language Training or the Mentoring Partnership. Furthermore institutions like the Immigrant Employment Councils and Local Immigration Partnerships offer support [1: 49ff.]. Overall Canada lacks in a unified process regarding the recognition of foreign qualifications a national qualification frameworks as well as the principle of mutual recognition [16: 32].

\section{Australia}

Skilled migration remains a national priority of the Australian government in the coming period within professional and trade fields. The political background for the recognition of foreign qualifications in Australia is to meet long-term workforce demand through expanded domestic training, medium-term demand through the General Skilled Migration programme, and short-term demand through employeror state-sponsored temporary migration [Government of Australia, 2008; Rudd et al., 2007 in 9: 204]. Three main pillars have formed within the area of permanent migration since 1988 - the "skill stream", the "family stream" and the "Humanitarian Program". Increasing focusing on economic policy aspects caused the skill stream to grow from about 20 percent in the mid1980 's to 68 percent in 2012, whilst the proportion taken up by the family stream declined accordingly [11:1]. Skill stream and family stream together form the Migration Program. Every year in May, precise target figures are published for all three streams [11:1 and 6].

Since 1999 the following key policy measures have included: mandatory pre-migration screening of credentials (undertaken on a fee for service basis by national or state/territory regulatory and other bodies); mandatory pre-migration English language assessment (with defined threshold standards required for speaking, listening, reading and writing); allocation of bonus points for migrants qualified in high-demand fields as well as immediate eligibility for international students to apply for skilled migration [9: 204].

The skilled worker requirement is expressed in the so-called Skilled Occupation List (SOL), which is drawn up on an annual basis by the Australian Workforce and Productivity Agency in consultation with the federal states and territories and the social partners. The SOL is the key specification both for employer-sponsored and workplace-independent migration within the scope of General Skills Migration. Potential labour migrants receive points for school and vocational qualifications, occupational experience, age, knowledge of English and further skills of relevance to the labour market. Every year, a minimum number of points which applicants need to achieve is stipulated [4: 2]. Due to the large number of applications, the skill stream procedure was altered on 1 July 2012. Within the framework of the new process, which is called "SkillSelect", foreign skilled workers now only have the opportunity to indicate their interest in a place in the skill stream. They are not permitted to submit an 
application until called upon to do so by the Department of Immigration. For this reason, the various shortage occupation lists for the skill stream have been collated into one list, the so-called Consolidated Sponsored Occupation List (CSOL) [11: 6]. Alongside consideration of the companies, since 2011 a certain number of places within the Migration Program have been allocated to the federal states and territories, which are able to undertake sponsoring within the scope of their own State Migration Plans and on the basis of their own lists of shortage occupations [11: 5].

The central characteristic of limited migration is the strict limitation to workers who are in particular demand on the basis of so-called 457 visas, which are awarded to "fast-track workers" in high-demand fields on the basis of the SOL [9: 202]. In the context of the marked privatization of Australia's skilled migration programme the scale of permanent arrivals has been supplemented by temporary labour migration in recent years. Additional 100,000-135,000 sponsored migrants are admitted annually on the basis of the points-based selection criteria, which is Australia's previous labor migration norm. For this employer-driven migration category there is no cap and it allows work rights of up to four years [9: 204].

There are a total of 450 assessment authorities in Australia. The National Office for Overseas Skills Recognition (NOOSR) ${ }^{3}$ is of particular significance for occupations that require formal recognition in accordance with the levels of the Australian Qualifications Framework (AQF). The NOOSR compares foreign education and training certificates and occupational experiences with the domestic training standards of the $\mathrm{AQF}$ either on a paper or a competency base (depending on jurisdictional requirements) [9: 213].

\section{Results and conclusion}

In all countries investigated, the question of whether and how recognition can be obtained for qualifications acquired abroad is closely interlinked with the political agenda and thus extends beyond the educational policy dimension.

Vocational qualifications, which are primarily the result of a vocational learning process (i.e. training), thus become the hinge between the labour market and the educational system. There seem to be no problems if a vocational qualification is acquired in the same country in which it is to be utilised on the labour market. In countries with dual vocational education and training systems, the qualification itself is the

${ }^{3}$ http://www.aqf.edu.au/Overseas/WorkingandlivinginAustralia/tabid /199/Default.aspx result of negotiating processes between the social partners. However, vocational qualifications achieved within a state VET system are also "legible" by companies in school-based systems. The labour market stakeholders know which occupational competences are possessed by a person who has acquired a certain vocational qualification. Trust prevails between the labour market (the party that accepts qualifications) and the educational system (the producer of qualifications). This trust has its foundations in occupational standards that are either developed jointly or else represented in a clearly communicated and transparent manner. Trust does not stop at national borders. Vocational qualifications are no long selfexplanatory within a different national, cultural, linguistic or labour market related context. Vocational qualifications and diploma acquired abroad do not immediately reveal themselves to the labour market representatives. The main thing that remains unclear is the question of which occupational competences are concealed behind a certain vocational qualification. Where can the workers be deployed? What tasks can they take on? How do the qualifications relate to those held by workers trained in the country of immigration? The fact that recognition of vocational qualifications takes place within the context of the conflicting relationships between collective wage agreements and free competition, between supply and demand and between various cultures in the educational system itself and in the world of work means all of these questions are relevant. Qualifications are not comparable per se, either across Europe or internationally. The main reason why this is so is that they are acquired in very different cultural, economic and traditional contexts. What is a vocational qualification worth outside its domestic frame of reference? Or, in other words, what procedures are required in order to establish the relative value of a qualification obtained abroad?

In all four countries, the recognition of qualifications acquired abroad is originally linked with a shortage of skilled workers. Against this background, recognition and assessment serve the purpose of formalising within the host country the occupational skills and competences that someone has acquired in another country and which can be demonstrated by qualifications and certificates with reference to the host country's existing occupational standards or to the labour markets. The pathways and underlying principles via which this takes place differ. In Europe, the aims of the recognition of professional and vocational qualifications are to secure freedom of movement of labour, support the creation of the European common market, and drive forwards skills competition and dynamise the European labour market in overall terms [14]. Regulated occupations are 
subject to a European Directive that is implemented into national law and is thus recognised de jure in all EU member states.

In addition to this, Denmark and Germany have laws in place that give the holders of qualifications that are non-regulated in the respective countries the right to recognition or assessment. The laws perform a double function. On the one hand, they exert an external effect by appealing to persons intending to migrate (recruitment function). To the same extent, however, they also target people who already live in the countries and who have not as yet been adequately able to exploit their qualifications on the respective labour markets (integration function). The formalisation of how this recognition takes place differs in Denmark and Germany.

The principles can be contoured by the question, whether the approaches/regulations are directed towards the verification of a full equivalence to the reference qualification/occupation or whether a more "basic comparability" shall be confirmed. However, having the foreign qualification assessed against the reference qualification can deliver some benefits for the applicant, e.g. the foreign qualification becomes "legible" and understandable for the employers by comparing it to the German and/or Danish qualification. First and foremost the notice of "basic comparability" or equivalence confers the same legal rights as a German or Danish qualification - which is of great importance on labour markets that are structured by occupations and characterized by collective bargaining agreements.

The Danish approach towards the recognition of foreign qualifications and competences focuses on learning outcomes considering that these can be achieved via different routes. As Denmark implemented its approach already in 2000 the country meanwhile also has profound experience within this area. Besides this like Australia and Canada a couple of European member states have adopted points-based systems for the selection of immigrants, which are often related to shortage occupations lists. Denmark is one European example having adopted such a pointsbased system since 2008. Within the Australian and the Canadian points-based system the latest changes show a significant orientation more towards general human capital rather than towards specific occupations. In both countries especially the language skills and the level of qualifications/education play an important role in the recent past. At the same time Australia and Canada tend to review and partly revise their temporary work programs [17: 103f.]. As huge territory countries they both also try to foster migration to regions outside of the major cities.

Overall the analyzed national examples show that elements like a points-based system, regional migration programs and a certain adjustment towards the endemic occupational skills shortages especially via shortage occupation lists are quite common elements of the national approaches. Still the institutional structures, the involved stakeholders and their roles as well as the concrete used methods differ.

In Canada and Australia, the recognition of professional and vocational qualifications is an essential criterion for the receipt of a work and residence permit. Commonalities are displayed with regard to the following aspects.

- The clear alignment of migration policy to the requirements of the labour market ("recognition as a steering element")

- The expansion of temporary migration at the expense of permanent migration

- The use of similar instruments to control migration (points systems, lists of shortage occupations, bridging programmes)

- The diversity of the stakeholders integrated into the recognition process

- The central role of the employers for recognition in the area of non-regulated occupations - supported by national assessment institutions in each case

- The use of credential/paper-based as well as competence-based assessment methods

To this extent, the recognition of foreign professional and vocational qualifications is the instrument of an "active immigration policy with an integrated selection mechanism". The relevant prevailing skilled worker requirements are decisive for recognition rather than primarily the qualification.

From the perspective of the MoVA Project, the country examples listed reinforce two of the assumptions guiding our research.

(1) In terms of supporting the implementation of the German Recognition Act, particular relevance is attached to countries which have a national recognition law and/or in the past have recruited high levels of skilled workers from third countries. The supposition is that these countries intend to go much further than Germany in applying "low-threshold" competence assessment procedures (i.e. procedures located below the regulatory policy level) which are also aligned towards the identification of informal competences.

(2) The political will for more professional and vocational recognition of qualified nationals, residents and immigrants conflicts with protection of the occupational structure and the quality standards associated with this (Germany/Denmark). For countries which have a different idea of "occupations" or "qualifications", recognition models are predominantly based on criteria exploitable on the labour market and/or inclusive criteria (Canada/Australia). 


\section{References}

[1] BERLIN-INSTITUT FÜR BEVÖLKERUNG UND ENTWICKLUNG (2012): Nach Punkten vorn. Was Deutschland von der Zuwanderungs- und Integrationspolitik Kanadas lernen kann, Berlin

[2] Beyer PAulsen, M. (2008): Freedom of movement: from right to possibility. Recognition of qualifications through legislation or information, in: European Journal of Vocational Training No 42/43-2007/2003. 2008/1, p. 19-32, http://www.cedefop.europa.eu/etv/Upload/Information_resou rces/Bookshop/491/42_en_BeyerPaulsen.pdf (access: 02.05.2012)

[3] BUNDESMINISTERIUM FÜR BILDUNG UND FORSCHUNG (2014): Bericht zum Anerkennungsgesetz. Beschluss des Bundeskabinetts vom 2. April 2014, Berlin. URL: http://www.bmbf.de/pub/bericht_anerkennungsgesetz_2014. pdf (access: 14.04.2014)

[4] Bundeszentrale Für POltistshe Bildung (2010): Fokus Migration. Australien, Nr. 21, Hamburg

[5] DANISH Ministry FOR EDUCATION: A visionary and innovative law, URL: http://www.anerkennung-indeutschland.de/html/en/danish_ministry_of_education.php (access: 17.04.2014)

[6] Foreign CRedentials Referral OfFice (2012): Strengthening Canada's Economy. Government of Canada Progress Report 2011 on Foreign Credential Recognition, Ottawa

[7] GERMAN CONFEDERATION of Skilled Crafts, URL: http://www.anerkennung-in-deutschland.de/html/ en/german_confederation_of_skilled_crafts.php (access: 14.04.2014)

[8] Guo, S.; Shan, H. (2013): Canada. In: International Organization for Migration: Recognition of qualifications and competences of migrants, p. 229-253, Brussels

[9] Hawthonne, L. (2013): Australia. In. International Organization for Migration: Recognition of qualifications and competences of migrants, p. 201-208, Brussels

[10] IHK FOSA, URL: http://www.anerkennung-indeutschland.de/html/en/ihk_fosa.php (access: 14.04.2014)

[11] Kaulisch, T. (2012): Australien. Migrationspolitik als Wachstumsmotor, Friedrich-Ebert-Stiftung, Berlin

[12] LARSEN, J. O. (2012): Recognition of foreign qualifications in Denmark, Berufsbildung in Wissenschaft und Praxis (BWP) 5, p. 40-43, URL: http://www.bibb.de/veroeffentlichungen/de/bwp/show/id/694 9 (access: 02.05.2013)

[13] LibRARY BRIEFING (2013). Library of the European Parliament, 03/10/2013, 130652REV1, URL: http://www.europarl.europa.eu/RegData/bibliotheque/briefin
g/2013/130652/LDM_BRI(2013)130652_REV1_EN.pdfhttp: //www.europarl.europa.eu/RegData/bibliotheque/briefing/20 13/130652/LDM_BRI(2013)130652_REV1_EN.pdfhttp://w ww.europarl.europa.eu/RegData/bibliotheque/briefing/2013/ 130652/LDM_BRI(2013)130652_REV1_EN.pdfhttp://www. europarl.europa.eu/RegData/bibliotheque/briefing/2013/1306 52/LDM_BRI(2013)130652_REV1_EN.pdf (access 17.04.2014)

[14] MaschmanN, A. (2011): Deutsch-dänische Grenzübergänge in der Berufsbildung, bwp@ Spezial-HT 2011, URL: http://www.bwpat.de/ht2011/kv/maschmann_kvht2011.pdf (access: 02.05.2012)

[15] MAYRING, P. (2002): Einführung in die qualitative Sozialforschung, Weinheim.

[16] McKenna, M. (2012): Brain Gain, Waste, and Drain: Canadian Foreign Credential Recognition. A comparison with Australia and New Zealand, Ottawa

[17] OECD: International Migration Outlook. Paris 2012.[18] PEDERSEN, A. B. (2010): Stellungnahme. Öffentliches Fachgespräch „Verbesserte Anerkennung ausländischer Abschlüsse und Berufsqualifikationen am 5. Juli 2010 (deutsche Übersetzung), Deutscher Bundestag, Ausschuss für Bildung, Forschung und Technikfolgenabschätzung, A - Drs 17(18)82 h (01.07.2010). http://www.bundestag.de/bundestag/ ausschuesse17/a18/anhoerungen/auslaendische_abschluesse/ ADrs_17-82_h.pdf (access 20.05.2012)

[19] TeICHLER, U. (1995): Qualifikationsforschung, in: Arnold, Rolf; Lipsmeier, Antonius (Hrsg.): Handbuch der Berufsbildung, Opladen 1995, S. 501-508 